\title{
Soil macrofauna under integrated crop-livestock systems in a Brazilian Cerrado Ferralsol
}

\author{
Robélio Leandro Marchão(1), Patrick Lavelle ${ }^{(2)}$, Leonide Celini( ${ }^{(3)}$, Luiz Carlos Balbino(4), Lourival Vilela(1) \\ and Thierry Becquer ${ }^{(5)}$
}

\begin{abstract}
(1)Embrapa Cerrados, Caixa Postal 08223, CEP 73310-970 Planaltina, DF, Brazil. E-mail: robelio.leandro@cpac.embrapa.br, Ivilela@cpac.embrapa.br (2)Institut de Recherche pour le Développement (IRD), 32, Avenue Henri Varagnat, 93143 Bondy, France. E-mail: patrick.lavelle@bondy.ird.fr (3)Université de Paris 12, Val de Marne, Faculté des Sciences et Technologies, 61, Avenue du Général de Gaulle, 94000 Créteil, France. E-mail: celini@univ-paris12.fr ${ }^{(4)}$ Embrapa Transferência de Tecnologia, Parque Estação Biológica, Avenida W3 Norte, Final, CEP 70770-901 Brasília, DF, Brazil. E-mail: luizcarlos.balbino@embrapa.br ${ }^{(5)} \mid R D$, SupAgro, 2 Place Viala, 34060 Montpellier, France. E-mail: thierry.becquer@ird.fr
\end{abstract}

\begin{abstract}
The objective of this work was to assess the effects of integrated crop-livestock systems, associated with two tillage and two fertilization regimes, on the abundance and diversity of the soil macrofauna. Four different management systems were studied: continuous pasture (mixed grass); continuous crop; two croplivestock rotations (crop/pasture and pasture/crop); and native Cerrado as a control. Macrofauna was sampled using a modified Tropical Soil Biology and Fertility method, and all individuals were counted and identified at the morphospecies level for each plot. A total of 194 morphospecies were found, distributed among 30 groups, and the most representative in decreasing order of density were: Isoptera, Coleoptera larvae, Formicidae, Oligochaeta, Coleoptera adult, Diplopoda, Hemiptera, Diptera larvae, Arachnida, Chilopoda, Lepidoptera, Gasteropoda, Blattodea and Orthoptera. Soil management systems and tillage regimes affected the structure of soil macrofauna, and integrated crop-livestock systems, associated with no-tillage, especially with grass/legume species associations, had more favorable conditions for the development of "soil engineers" compared with continuous pasture or arable crops. Soil macrofauna density and diversity, assessed at morphospecies level, are effective data to measure the impact of land use in Cerrado soils.
\end{abstract}

Index terms: biodiversity, crop-pasture rotation, no-tillage, soil invertebrates, soil quality.

\section{Macrofauna edáfica em sistemas de integração lavoura-pecuária num Latossolo Vermelho do Cerrado}

Resumo - O objetivo deste trabalho foi avaliar os efeitos de sistemas de integração lavoura-pecuária, associados a dois tipos de preparo e de fertilização do solo, sobre a abundância e a diversidade da macrofauna edáfica. Quatro sistemas de manejo foram estudados: pastagem contínua de gramíneas; lavoura contínua de culturas anuais; dois sistemas integrados lavoura-pecuária (lavoura/pastagem e pastagem/lavoura); e Cerrado nativo (controle). A macrofauna foi avaliada pelo método "Tropical Soil Biology and Fertility" modificado e todos os indivíduos coletados nas parcelas foram contados e identificados ao nível de morfoespécies. O total de 194 morfoespécies foi encontrado, distribuído entre 30 grandes grupos, dos quais os mais representativos em ordem decrescente de densidade foram: Isoptera, larvas de Coleoptera, Formicidae, Oligochaeta, adultos de Coleoptera, Diplopoda, Hemiptera, larvas de Diptera, Arachnida, Chilopoda, Lepidoptera, Gasteropoda, Blattodea e Orthoptera. Os sistemas de uso e de preparo do solo afetaram a estrutura das comunidades da macrofauna edáfica. Os sistemas de integração lavoura-pecuária, associados ao plantio direto na fase lavoura, especialmente com a rotação gramíneas/ leguminosas, tiveram as melhores condições para o desenvolvimento das espécies de "engenheiros do solo" em comparação às pastagens e às culturas contínuas. A densidade e a diversidade da macrofauna, avaliadas em nível de morfo-espécies, são dados eficientes para medir o impacto de diferentes sistemas de uso da terra, em solos do Cerrado.

Termos para indexação: biodiversidade, rotação lavoura-pastagem, plantio direto, invertebrados do solo, qualidade do solo.

\section{Introduction}

In general, invertebrate communities seem to be best conserved in derived system with structure similar to that of the original system, such as pastures planted in savanna areas and tree-based systems in forest areas (Benito et al., 2004; Decaëns et al., 2004; Silva et al., 2006). However, an increase in the intensity of agricultural practices and the establishment of continuous pastures or annual crops have caused

Pesq. agropec. bras., Brasília, v.44, n.8, p.1011-1020, ago. 2009 
important changes in the community structure, abundance and biomass of soil macrofauna. Fragoso et al. (1997) studied earthworm communities and observed lower species richness, lower number of native species, lower number of ecological groups, and a predominance of endogeic species in agroecosystems.

Traditional agriculture and livestock production systems, developed in the Cerrado region, are rather unsustainable (Brossard \& López-Hernández, 2005). Intensive crop production systems, although highly productive, make increasing use of fertilizers and agrochemicals. Extensive livestock production system, based on the exploitation of the natural fertility, leads to a decline in the productivity of pasture and to soil degradation. Estimates show that approximately $80 \%$ of the Cerrado pasture soils have various stages of degradation, which causes low cattle productivity and soil and water degradation. Additionally, intensive agriculture associated with conventional tillage may harm the environment due to soil organic matter losses through soil mineralization and erosion. This condition is mainly caused by degradation of the physical properties and the inherent low chemical fertility of these soils (Balbino et al., 2004). More recently, integrated crop-livestock systems (ICLS) have been recommended in Brazil, and have increased production of both crop and livestock by the intensification of land use. Like other integrated systems, ICLS seem to be best for conserving diversity and sustaining high levels of abundance of the soil macrofauna (Silva et al., 2006), and are strongly supported by agronomic research in Brazil.

In the Cerrado region, only few studies (Benito et al., 2004; Silva et al., 2006; Aquino et al., 2008) have been carried out on pastures or crop systems, notably in long-term conditions; therefore, there is a lack of information on this important agricultural Brazilian region. The adoption of ICLS based in no-tillage would have a favorable effect on the development of an abundant and diverse soil and litter fauna, which in turn would assist in restoring soil fertility and site productivity.

The objective of this work was to assess the effects of ICLS, associated with two tillage and fertilization regimes, on the abundance and diversity of the macrofauna in comparison with continuous crops or pasture.

\section{Materials and Methods}

The site is located at Embrapa Cerrados $\left(15^{\circ} 35^{\prime} \mathrm{S}\right.$, $47^{\circ} 42^{\prime} \mathrm{W}, 1,200 \mathrm{~m}$ altitude), on a plateau in the center of the Cerrado region, near Planaltina county, DF, Brazil. The mean annual temperature is $26^{\circ} \mathrm{C}$, and the average annual rainfall is about $1,200 \mathrm{~mm}$, with more than $80 \%$ of the rainfall occurring between November and April. The soil is an Orthic Ferralsol (Food and Agriculture Organization of the United Nations, 2006), or clayey "Latossolo Vermelho" according to the Brazilian classification (Santos et al., 2006).

In 1991, the native Cerrado vegetation was removed, and dolomitic lime was applied before the establishment of the field experiment. Four different land-use systems were studied: continuous crop; continuous pasture; and ICLS in a 4-year rotation cycle ending by pasture (pasture/crop), or by crop (crop/pasture). These system were combined with two tillage regimes (no-tillage, conventional tillage), and two fertilization regimes (maintenance and corrective fertilization) (Marchão et al., 2009) (Table 1). The amounts of fertilizers applied in the 1991-2003 period, on each of the fertilization regimes, are briefly detailed in Table 2. The plots occupied by the pastures were grazed every year in the rainy season. The dimensions of each plot were 40x50 m.

Macrofauna was sampled according to the Tropical Soil Biology and Fertility (TSBF) method, with modifications (Lavelle, 1988). Samples were taken at the end of a 4-year rotation cycle, in May 2004. Three $25 \times 25 \mathrm{~cm}$ soil monoliths were taken from each plot on regular transects. The fauna was sampled and sorted in the litter layer before soil blocks were excavated. Each monolith was cut from three horizontal layers $(0-10,10-20$ and $20-30 \mathrm{~cm})$. Soil invertebrate macrofauna specimens, i.e., organisms with a body diameter greater than $2 \mathrm{~mm}$, were extracted and stored in a $70 \%$ alcohol solution. Earthworms were preserved in 4\% formaldehyde. All individuals were counted and identified at the morphospecies levels (i.e. morphologically identical groups of individuals), in the soil ecology laboratory of the Institute of Research for Development (IRD), at Bondy, France. Total density and diversity at morphospecies levels were determined for each plot. Subsequently, the mean and standard error of the density in each group were calculated for each management system, tillage and fertilization regimes. For data analysis and discussion 
of the results, the Coleoptera group was subdivided into larvae and adults. We considered that adults and larvae of Coleoptera can have different roles in soil function, acting as micropredators, litter transformers or "ecosystem engineers" (Lavelle et al., 1993). To compute total soil diversity as morphospecies richness in each plot (Table 3), we considered only larvae of Coleoptera. The other groups found were Isoptera, Formicidae, Oligochaeta, Diplopoda, Chilopoda, Diptera, Hemiptera, Lepidoptera, Arachnida, Blattodea, Gasteropoda and Orthoptera.

A principal component analysis (PCA) was performed, without data transformation, using the ADE-4 software (Thioulouse et al., 1997) on a matrix composed of 14 lines (sampled systems) and 8 or 10 columns (for the morphospecies richness and density attributes of macrofauna communities, respectively). The analysis was done with density and morphospecies richness data of the different management systems, tillage and fertilization regimes; and permutation tests allowed testing for the significance of differences between management systems, tillage and fertilization regimes. In order to have fewer variables than sites, a specific requisite for multivariate analyses, we grouped taxa as follows: Coleoptera adults; Coleoptera larvae; Isoptera; Formicidae; Oligochaeta; Diptera larvae; Hemiptera, Lepidoptera, Arachnida, Blattodea, Gasteropoda and Orthoptera combined as "other litter invertebrates"; Diplopoda and Chilopoda grouped as Myriapoda.

To facilitate the discussion of the results, data are shown for soil management systems and tillage and fertilization regimes according to the following growing gradient of land use intensification: tillage intensity-Cerrado, continuous pasture, pasture-crop rotation, crop-pasture rotation, continuous crop; soil disturbance - no-tillage, conventional tillage; use of fertilizers - maintenance fertilization, corrective fertilization.

\section{Results and Discussion}

The highest total soil faunal density ocurred in the Cerrado vegetation (4,788 individuals $\mathrm{m}^{-2}$ ), and the lowest in the continuous crop system (997 individuals $\mathrm{m}^{-2}$ ) (Table 3 ). In Cerrado, the total density $\left(4,788\right.$ individuals $\left.\mathrm{m}^{-2}\right)$ comprised nine groups. However, $95 \%$ of this total density was represented by two groups, Isoptera $\left(4,340\right.$ individuals $\left.\mathrm{m}^{-2}\right)$ and Formicidae (244 individuals $\mathrm{m}^{-2}$ ). Typical environmental conditions of Cerrado, such as poor litter quality, e.g. high $\mathrm{C} / \mathrm{N}$ ratio of plant tissues, occurrence of vacant niches (microhabitats), and reduced temperature at the soil surface, may explain the significant increase of Isoptera density (Constantino, 2005). Our results confirm the ones obtained by Dias et al. (1997) and Benito et al.

Table 1. Land use systems studied in the field experiment.

\begin{tabular}{|c|c|c|c|c|}
\hline Land use system & Tillage regime & Fertilization regime $^{(1)}$ & Annual sequence of crops $1991-2004^{(2)}$ & Symbols \\
\hline Cerrado & - & - & - & Cerr \\
\hline Continuous pasture & - & $\mathrm{F} 2$ & $\mathrm{Ag}-\mathrm{Ag}-\mathrm{Ag}-\mathrm{Ag}-\mathrm{Ag}-\mathrm{Ag}-\mathrm{Ag}-\mathrm{Ag}-\mathrm{Ag}-\mathrm{Bd}-\mathrm{Bd}-\mathrm{Bd}-\mathrm{Bd}$ & Past \\
\hline \multirow{4}{*}{ Pasture/crop rotation } & No-tillage & F1 & \multirow{4}{*}{$\mathrm{Ag}-\mathrm{Ag}-\mathrm{Ag}-\mathrm{Ag}-\mathrm{M}-\mathrm{S}-\mathrm{M}-\mathrm{S}-\mathrm{Pm}-\mathrm{Pm}-\mathrm{Pm}-\mathrm{Pm}-\mathrm{Pm}$} & PR NT F1 \\
\hline & & $\mathrm{F} 2$ & & PR NT F2 \\
\hline & Conventional tillage & $\mathrm{F} 1$ & & PR CT F1 \\
\hline & & $\mathrm{F} 2$ & & PR CT F2 \\
\hline \multirow{3}{*}{ Crop/pasture rotation } & No-tillage & F1 & $\mathrm{S}-\mathrm{S}-\mathrm{M}-\mathrm{S}-\mathrm{Ag}-\mathrm{Ag}-\mathrm{Ag}-\mathrm{Ag}-\mathrm{S}-\mathrm{Pg}-\mathrm{S}-\mathrm{Pg}-\mathrm{Bb}-\mathrm{Bb} / \mathrm{S}^{(3)}$ & CR NT F1 \\
\hline & Conventional tillage & $\mathrm{F} 1$ & \multirow{2}{*}{$\begin{array}{c}\mathrm{S}-\mathrm{S}-\mathrm{M}-\mathrm{S}-\mathrm{Ag}-\mathrm{Ag}-\mathrm{Ag}-\mathrm{Ag}-\mathrm{S}-\mathrm{Pg}-\mathrm{S}-\mathrm{Pg}-\mathrm{Bb}- \\
\text { Ploughed Soil }\end{array}$} & CR CT F1 \\
\hline & & $\mathrm{F} 2$ & & CR CT F2 \\
\hline \multirow{4}{*}{ Continuous Crop } & No-tillage & $\mathrm{F} 1$ & \multirow{4}{*}{$\mathrm{S}-\mathrm{S}-\mathrm{M}-\mathrm{S}-\mathrm{M}-\mathrm{S}-\mathrm{M}-\mathrm{S}-\mathrm{S}-\mathrm{Pg}-\mathrm{S}-\mathrm{Pg}-\mathrm{S}-\mathrm{S}$} & C NT F1 \\
\hline & & $\mathrm{F} 2$ & & C NT F2 \\
\hline & Conventional tillage & $\mathrm{F} 1$ & & C CT F1 \\
\hline & & $\mathrm{F} 2$ & & $\mathrm{C} \mathrm{CT} \mathrm{F2}$ \\
\hline
\end{tabular}

${ }^{(1)}$ For the crops, maintenance fertility (F1) corresponded to the fertilization calculated from the expected grain yield and nutrient export; corrective fertility (F2) was determined, in order to gradually increase the level of phosphorus in the soil (see Table 2). For the pasture phase in ICLS, maintenance fertility meant no fertilizer was applied. ${ }^{(2)} \mathrm{Ag}$, Andropogon gayanus var. bisquamulatus (Hochst.) Stapf. cv. Planaltina; Bd, Brachiaria decumbens (Stapf); M, Maize; S, Soybean; Pm, Panicum maximum Jacq. cv. Tanzânia; Pg, Pennisetum glaucum (L.) R. Br.; Bb, Brachiaria brizantha (Hochst.) Stapf. cv. Marandu. (3)In the ICLS crop-pasture rotation with no-tillage system (CR NT), introduction of the pasture occurred at the same time in which crop sowing took place. The seeds of the pasture were mixed with the crop fertilizer before sowing. 
(2004) for the Brazilian Cerrado, who reported a high density of Isoptera. However, despite the high density, only three Isoptera morphospecies were identified. Silva et al. (2006) also observed a high Isoptera density in the integrated crop-livestock rotation systems, and in the continuous pasture (mixed grass), but they did not report the number of species identified. According

Table 2. Amount of fertilizers applied in 1991-2003 period, in the field experiment.

\begin{tabular}{|c|c|c|c|c|c|}
\hline \multirow[t]{2}{*}{ Management system } & Lime $^{(1)}$ & Gypsum $^{(2)}$ & $\mathrm{N}$ & $\mathrm{P}$ & $\mathrm{K}$ \\
\hline & \multicolumn{5}{|c|}{-------- $\left(\mathrm{Mg} \mathrm{ha}^{-1}\right)$-------- } \\
\hline & \multicolumn{5}{|c|}{ Maintenance fertilization } \\
\hline Continuous crop & 4.4 & 0 & 120 & 261 & 400 \\
\hline Crop-pasture rotation & 4.4 & 0 & 40 & 178 & 273 \\
\hline Pasture-crop rotation & 1 & 0 & 120 & 144 & 178 \\
\hline \multirow[t]{2}{*}{ Continuous pasture } & 1 & 0 & 40 & 85 & 123 \\
\hline & \multicolumn{5}{|c|}{ Corrective fertilization } \\
\hline Continuous crop & 7.5 & 2.8 & 235 & 494 & 891 \\
\hline Crop-pasture rotation & 7.5 & 2.8 & 85 & 337 & 621 \\
\hline Pasture-crop rotation & 7.5 & 0 & 190 & 224 & 326 \\
\hline Continuous pasture & 6.8 & 0 & 80 & 111 & 175 \\
\hline
\end{tabular}

${ }^{(1)}$ Dolomitic lime. ${ }^{(2)}$ Humidity content, $22.6 \%$. to Benito et al. (2004), the conversion of Cerrado into pastures or crops induced important modifications. In the short run, the soil volume could only be colonized by taxonomic groups, which are able to accept the new organic resource. At the same time, the lower plant diversity favors some groups, which may consume the available green forage, therefore becoming pests, as for example some Isoptera (Syntermes) in Cerrado pastures (Constantino, 2005).

Total density decreased according to the intensification of land use, being especially low in the continuous soil management system (Table 3). ICLS and continuous pasture had an intermediate condition in this gradient. Moreover, the crop areas in no-tillage systems had higher macrofaunal densities, when compared to conventional tillage. In no-tillage systems, a significant increase in density of the groups Coleoptera, Formicidae, Oligochaeta and Diplopoda was observed, which indicates a preference of these groups for the environment resulting from no-tillage

Table 3. Mean density $\pm \mathrm{SE}$, number of morphospecies (richness), and total number of morphospecies of soil macroinvertebrates per plot, in a Brazilian clayey Ferralsol, in different land use systems.

\begin{tabular}{|c|c|c|c|c|c|c|c|c|c|c|}
\hline \multirow[t]{2}{*}{ Fauna group } & \multicolumn{5}{|c|}{ Management systems } & \multicolumn{2}{|c|}{ Tillage regimes } & \multicolumn{2}{|c|}{ Fertilization regimes } & \multirow{2}{*}{$\begin{array}{l}\mathrm{N}^{\circ} \text { of species } \\
\text { richness in taxa }\end{array}$} \\
\hline & Cerrado & $\begin{array}{c}\text { Continuous } \\
\text { pasture }\end{array}$ & $\begin{array}{l}\text { Pasture-crop } \\
\text { rotation }\end{array}$ & $\begin{array}{c}\text { Crop-pasture } \\
\text { rotation }\end{array}$ & $\begin{array}{c}\text { Continuous } \\
\text { crop }\end{array}$ & No-tillage & $\begin{array}{c}\text { Conventional } \\
\text { tillage }\end{array}$ & $\begin{array}{c}\text { Maintenance } \\
\text { fertility }\end{array}$ & $\begin{array}{c}\text { Corrective } \\
\text { fertility }\end{array}$ & \\
\hline \multicolumn{11}{|c|}{ Density (individuals $\mathrm{m}^{-2}$ ) } \\
\hline Coleoptera adult & $16 \pm 3$ & $37 \pm 4$ & $32 \pm 4$ & $192 \pm 10$ & $152 \pm 8$ & $157 \pm 11$ & $98 \pm 8$ & $138 \pm 11$ & $106 \pm 9$ & - \\
\hline Coleoptera larvae & $80 \pm 5$ & $464 \pm 20$ & $530 \pm 16$ & $301 \pm 13$ & $229 \pm 15$ & $446 \pm 17$ & $241 \pm 13$ & $355 \pm 15$ & $360 \pm 17$ & - \\
\hline Formicidae & $244 \pm 9$ & $395 \pm 20$ & $82 \pm 9$ & $450 \pm 27$ & $240 \pm 16$ & $353 \pm 25$ & $167 \pm 16$ & $238 \pm 16$ & $305 \pm 24$ & - \\
\hline Isoptera & $4,340 \pm 77$ & $544 \pm 27$ & $316 \pm 26$ & $1,173 \pm 43$ & $251 \pm 15$ & $794 \pm 40$ & $370 \pm 25$ & $822 \pm 41$ & $401 \pm 26$ & - \\
\hline Oligochaeta & $24 \pm 4$ & $149 \pm 13$ & $153 \pm 16$ & $163 \pm 15$ & $35 \pm 7$ & $164 \pm 17$ & $64 \pm 9$ & $143 \pm 15$ & $100 \pm 14$ & - \\
\hline Diplopoda & $8 \pm 3$ & $21 \pm 3$ & $21 \pm 5$ & $62 \pm 8$ & $43 \pm 7$ & $70 \pm 8$ & $14 \pm 5$ & $35 \pm 7$ & $45 \pm 8$ & - \\
\hline Chilopoda & $44 \pm 6$ & 0 & $5 \pm 3$ & $5 \pm 3$ & 0 & $3 \pm 3$ & $3 \pm 3$ & $5 \pm 3$ & $2 \pm 2$ & - \\
\hline Diptera larvae & $8 \pm 4$ & $5 \pm 3$ & $23 \pm 5$ & $21 \pm 5$ & $5 \pm 3$ & $20 \pm 5$ & $11 \pm 5$ & $10 \pm 4$ & $19 \pm 5$ & - \\
\hline Hemiptera & 0 & $21 \pm 3$ & $16 \pm 4$ & $16 \pm 4$ & $16 \pm 4$ & $17 \pm 4$ & $15 \pm 4$ & $14 \pm 4$ & $19 \pm 4$ & - \\
\hline Lepidoptera larvae & 0 & $5 \pm 3$ & $2 \pm 2$ & $10 \pm 4$ & $6 \pm 3$ & $4 \pm 3$ & $8 \pm 4$ & $8 \pm 4$ & $4 \pm 3$ & - \\
\hline Arachnida & $20 \pm 5$ & 0 & $5 \pm 3$ & $3 \pm 3$ & $8 \pm 4$ & $9 \pm 4$ & $2 \pm 2$ & $5 \pm 3$ & $5 \pm 4$ & - \\
\hline Blattodeae & 0 & $5 \pm 3$ & 0 & $5 \pm 3$ & $2 \pm 2$ & $4 \pm 3$ & 0 & $2 \pm 2$ & $4 \pm 3$ & - \\
\hline Gasteropoda & 0 & 0 & $2 \pm 2$ & $10 \pm 4$ & $6 \pm 3$ & $12 \pm 4$ & 0 & $7 \pm 3$ & $4 \pm 3$ & - \\
\hline Orthoptera & $4 \pm 3$ & 0 & 0 & $2 \pm 2$ & $3 \pm 3$ & 0 & $3 \pm 3$ & $2 \pm 2$ & $2 \pm 2$ & - \\
\hline \multicolumn{11}{|c|}{ Total number of morphospecies per plot } \\
\hline Coleoptera adult & 4 & 5 & 7 & 24 & 28 & 27 & 26 & 25 & 30 & 40 \\
\hline Coleoptera larvae & 10 & 7 & 22 & 25 & 24 & 32 & 26 & 29 & 32 & 50 \\
\hline Formicidae & 20 & 11 & 12 & 22 & 19 & 25 & 22 & 27 & 20 & 60 \\
\hline Isoptera & 1 & 2 & 1 & 0 & 2 & 1 & 2 & 2 & 1 & 3 \\
\hline Oligochaeta & 2 & 3 & 4 & 4 & 3 & 5 & 5 & 4 & 5 & 5 \\
\hline Diplopoda & 2 & 2 & 4 & 4 & 2 & 4 & 2 & 4 & 3 & 4 \\
\hline Chilopoda & 2 & 0 & 3 & 2 & 0 & 2 & 3 & 3 & 2 & 4 \\
\hline Diptera larvae & 2 & 1 & 7 & 6 & 3 & 9 & 6 & 6 & 8 & 13 \\
\hline Hemiptera & 0 & 4 & 8 & 4 & 9 & 13 & 8 & 7 & 13 & 20 \\
\hline Lepidoptera larvae & 0 & 1 & 1 & 6 & 4 & 4 & 7 & 7 & 4 & 12 \\
\hline Arachnida & 5 & 0 & 3 & 2 & 5 & 8 & 2 & 4 & 6 & 15 \\
\hline Blattodeae & 0 & 1 & 0 & 3 & 1 & 3 & 0 & 1 & 2 & 3 \\
\hline Gasteropoda & 0 & 0 & 1 & 2 & 1 & 2 & 0 & 2 & 1 & 2 \\
\hline Orthoptera & 1 & 0 & 0 & 1 & 1 & 0 & 2 & 1 & 1 & 3 \\
\hline Total density & 4,788 & 1,648 & 1,188 & 2,411 & 997 & 2,053 & 998 & 1,782 & 1,376 & - \\
\hline Total diversity & 49 & 37 & 73 & 105 & 102 & 135 & 111 & 122 & 128 & $194^{(1)}$ \\
\hline
\end{tabular}

${ }^{(1)}$ Considering only Coleoptera larvae . 
system. In the continuous pasture of Brachiaria decumbens, we observed the presence of 10 groups. Overall, the pasture sites with Panicum maximum in rotation systems (PR) had a high density of Coleoptera larvae.

According to the PCA analysis of macrofauna density, the first two axis explained $47.2 \%$ of the total variance- axis 1 (27\%) and axis2 (20.2\%) (Figure 1 A). Axis1 distinguished communities with soil litter fauna dominance represented by adult Coleoptera, Myriapoda, Arachnida, Hemiptera, Blattodea (and other litter-dwelling invertebrates of the group called "others" - from those with a moderate density of these groups. Axis2 separated the systems characterized by Coleoptera larvae, Oligochaeta, Diptera larvae and Formicidae from those with greater abundance of Isoptera.

Permutation tests of site coordinates, for all extracted axes, showed a significant effect $(\mathrm{p}<0.01)$ of soil management systems on macrofauna communities, described by the abundance of the different orders (Figure 1 B). Axis1 separated the soybean continuous crop system (C) and the soybean crop in the crop/pasture rotation (CR) from the Cerrado (Cerr), the continuous

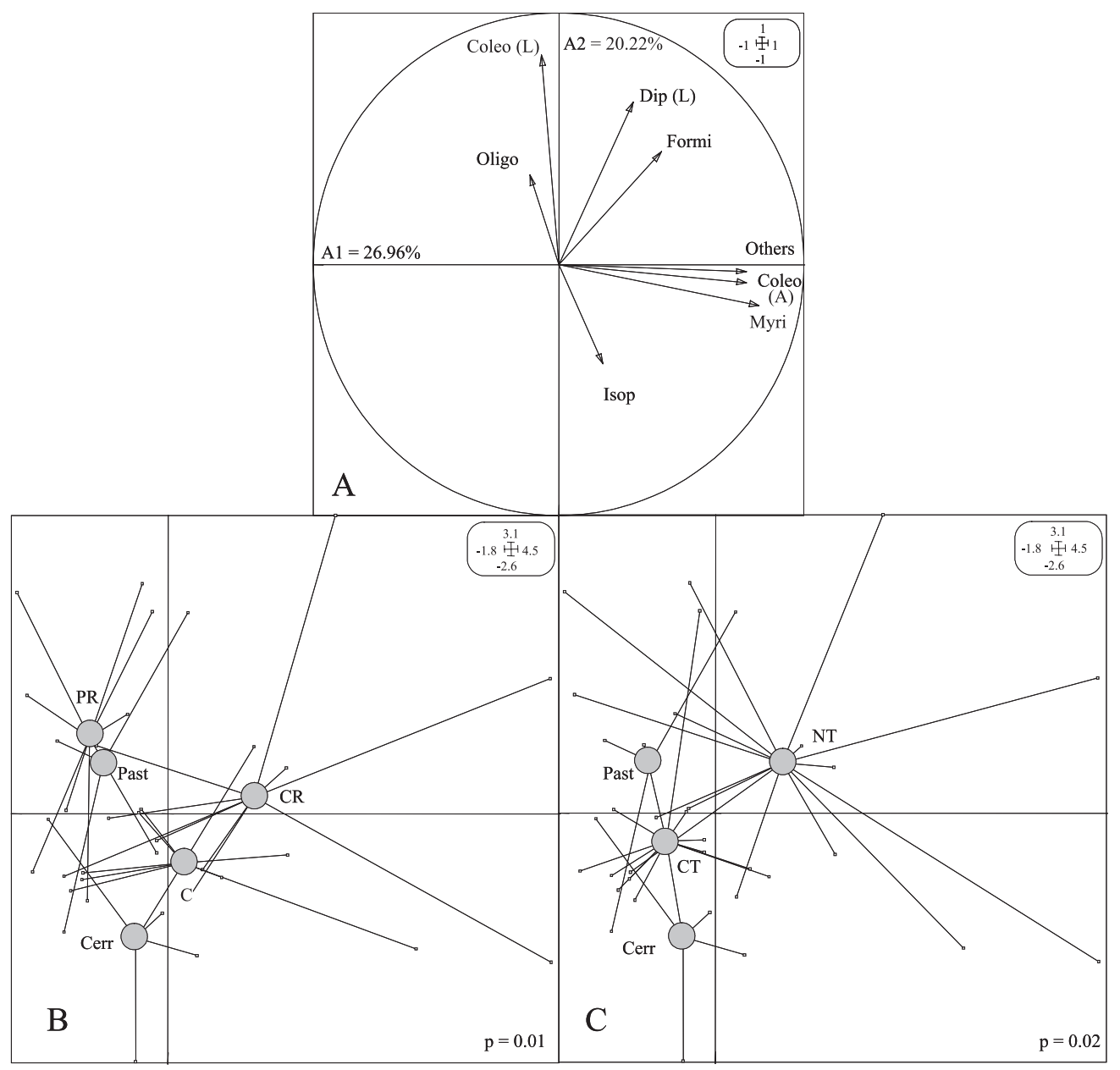

Figure 1. Principal component analysis of macroinvertebrate density, in different land use systems. A, correlation circle of macroinvertebrate taxa, with factorial axes A1 and A2; $\mathrm{B}$, projection of sites in the A1/A2 plane, according to land use systems; and C, occurrence of tillage. Cerr, Cerrado; C, continuous crop; CR, crop/pasture rotation; Past, continuous pasture; $\mathrm{PR}$, pasture/crop rotation; CT, conventional tillage; NT, no-tillage; $\mathrm{p}$, grouping probability by permutation test. Coleo (A), Coleoptera adult; Coleo (L), Coleoptera larvae; Myri, Myriapoda; Isop, Isoptera; Oligo, Oligochaeta; Formi, Formicidae; Dip (L), Diptera larvae; Others: other litter dwelling taxa. 
pasture (Past), and the pasture/crop rotation system with $P$. maximum at the time of the sampling (PR). Axis2 distinguished sites with high disturbance conditions from others, and also separated pasture and crop/pasture rotation (PR, CR and Past) systems from the continuous crop system (C) and Cerrado. The PCA analysis also showed a significant impact of the soil tillage system $(p=0.02)$ on the composition of soil macroinvertebrate communities. In Figure $1 \mathrm{C}$, Axis2 opposed cropping systems without soil tillage (NT) from those with conventional tillage (CT); pastures and the natural Cerrado plot remained on the side of convencional tillage systems. Axis1 opposed native plots of Cerrado and tilled systems to the other two systems, mainly on the basis of termite occurrence. The permutation tests did not show any significant effects on soil fertility levels $(\mathrm{p}<0.20)$.

Concerning macrofauna diversity, a total of 194 morphospecies were found, distributed among 30 groups (orders or families). In the soil management system and tillage type comparison (Table 3), the highest morphospecies richness was observed in the 4-year-old soybean, in the CR system (ICLS), and in the continuous crop system with 105 and 102 morphospecies, respectively. The lowest richness (mean of 37) was found in the continuous pastures (Past). Morphospecies richness in taxa was higher in the Coleoptera adults, Coleoptera larvae and Formicidae groups, with 40, 50 and 60 morphospecies identified, respectively. Despite the higher density of termites, in all samples, we identified only three termite morphospecies. The group Formicidae had the highest morphospecies richness, with 60 morphospecies from the subfamilies Myrmicinae, Formicinae and Panerinae. Dias et al. (1997) also observed a higher presence of the subfamilies Myrmicinae and Formicinae, in native areas of Cerrado. The groups Myriapoda (Diplopoda and Chilopoda), Diptera larvae, Hemiptera, Lepidoptera and Arachnida had also a higher diversity, with 8, 12, 20, 12 and 15 morphospecies identified.

The diversity of the macroinvertebrates found at the study sites was relatively high (194), compared with other sites studied in the tropics. For example, Decaëns et al. (2004), in a study on pastures derived from Colombian savanna, identified 29 families, 42 macroinvertebrate morphospecies and eight earthworm species. In the same study, in the Brazilian
Amazonrain forest, they identified 156morphoespecies. In native Cerrado, the diversity indexes were lower than in the systems with annual crops (CR and C), even in rotation (PR). These findings contrasted with what has generally been found in studies performed under native vegetation in Amazonia (Barros et al., 2002; Mathieu et al., 2005), in Argentine natural grasslands and fallows after rice fields (Thomas et al., 2004), and in the Brazilian Cerrado (Silva et al., 2006) where the authors observed higher diversity indexes in the native vegetation. We attribute this result to the effect of the presence of soybean in the crop systems, which promotes a high quality litter addition with a low C/N ratio. Santos et al. (2008) also showed a positive effect of leguminous species in a Cerrado soil macrofauna.

The PCA analysis for richness data (Figure $2 \mathrm{~A}$ ) showed that the first two axis explained $39.5 \%$ of the variance - Axis1 (20.6\%) and Axis2 (18.8\%). Axis1 distinguished communities with high species richness of Formicidae, Coleoptera adults, Myriapoda and "other litter invertebrates", which were the groups with high richness, from those with lower diversities (Figure 2 A and Table 3). Thus, Axis1 separated the continuous pasture, the continuous crop, the Cerrado (Cerr) and the crop-pasture rotation system (CR), from the pasture-crop rotation (PR) (Figure $2 \mathrm{~B}$ ).

Axis2 separated the systems characterized by the presence of Isoptera and Formicidae from those with a greater presence of Oligochaeta, Coleoptera larvae, Diptera larvae, Myriapoda, Coleoptera adults and other invertebrates. The latter group had a larger overall number of species. Axis2 distinguished sites with rotation ( $\mathrm{CR}$ and $\mathrm{PR}$ ) from the continuous systems ( $\mathrm{C}$ and Past) and Cerrado vegetation (Cerr) (Figure 2 B). Permutation tests showed a significant impact of types of land use and soil tillage on soil fauna communities $(p=0.001$ and $p<0.003$, respectively) (Figures $2 \mathrm{~B}, \mathrm{C}$ ), whereas the effect of the soil fertility level was not significant $(p<0.16)$.

In the cultivated areas, the richness of macroinvertebrate communities varied significantly, in relation to soil management and tillage regimes (Figures 2 B, C). In the CR system (covered with soybean/Brachiaria brizantha association at sampling), 105 morphoespecies were identified. A smaller number was observed in the continuous pastures (37) and in the pasture in rotation (73). 
The principal component analysis of frequency data clearly separated the ICLS systems (CR and PR) from the other systems (Figure $2 \mathrm{~B}$ ). In the correlation circle, we observed that Axis2 separated the systems with higher richness from systems with relatively poor diversity. No-tillage systems (NT) were also clearly separated from Cerrado and continuous pastures with regard to Axis2, and from conventional tillage with regard to Axis1. The crop/pasture rotation system (CR and PR), as well as the no-tillage system (NT) had a greater richness of Coleoptera larvae, Diptera larvae and Oligochaeta. This pattern is probably due to the quantity of organic matter produced by grasses, and a better quality of organic matter added by the soybean crop. No-tillage systems (NT) are also characterized by the density of Diptera larvae and Formicidae, along with the species of the litter.

The total macrofauna density had a quite different pattern in comparison with richness. Cerrado had a higher total density than the pasture and crops, and faunal activity was concentrated in the upper few centimeters of the soil, with an insignificant proportion of invertebrates in the litter (1\%). Most studies have shown similar results (Decaëns et al., 1994; Silva et al., 2006). The pasture systems (Past and PR) showed a high density of Oligochaeta, Coleoptera larvae, i.e. species specialized in bioturbation, creating biogenic structures and building stable porosity. A significant increase in

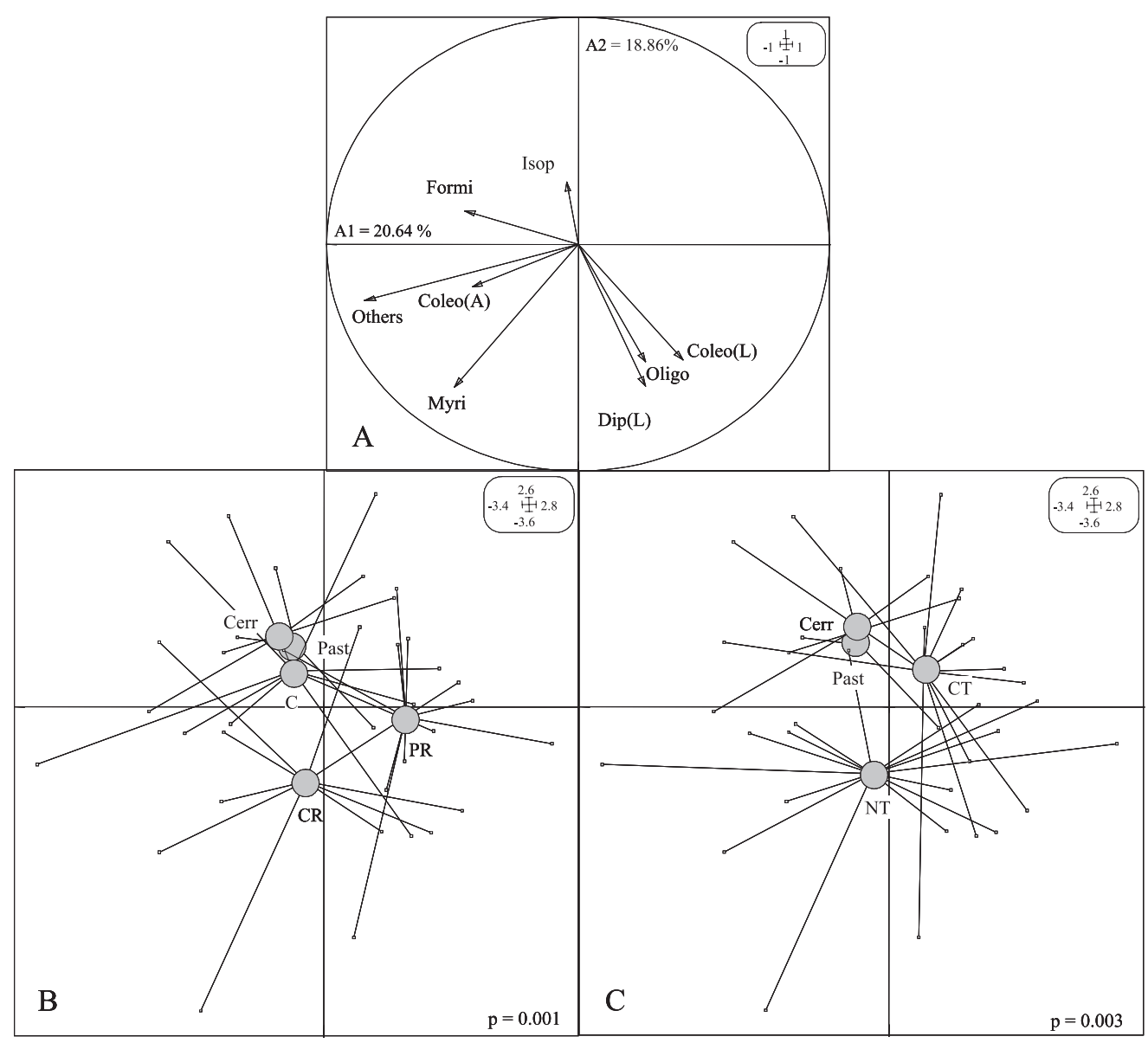

Figure 2. Principal component analysis of species richness in macroinvertebrate taxa, in different land use systems. A, Correlation circle of macroinvertebrate taxa with factorial axes A1 and A2; $\mathrm{B}$, projection of sites in the A1/A2 plane, according to land use systems; and $\mathrm{C}$, occurrence of tillage. Cerr, Cerrado; C, continuous crop; CR, crop/pasture rotation; Past, continuous pasture; $\mathrm{PR}$, pasture/crop rotation; $\mathrm{CT}$, conventional tillage; NT, no-tillage; $\mathrm{p}$, probability for groupings by permutation test. Coleo (A), Coleoptera adult; Coleo (L), Coleoptera larvae; Myri, Myriapoda; Isop, Isoptera; Oligo, Oligochaeta; Formi, Formicidae; Dip (L), Diptera; Others. 
earthworm density and biomass, in the pasture system, was observed in many tropical pastures (Brown et al., 2001, 2004). Even with low diversity, these systems seem to be favorable to the physical properties of the soil (Oades, 1993). Several micromorphological studies show the role of earthworms in the formation of galleries and aggregates (Barros et al., 2001). Blanchart et al. (1997) demonstrated the importance of earthworms on the pore size distribution and the stability of aggregates. The high density under crop pasture systems (CR) was largely accounted for by the variations in Coleoptera adults, Formicidae, Myriapoda and Isoptera.

Concerning vertical distribution, all the land use systems showed a clear concentration of invertebrates in the $0-20 \mathrm{~cm}$ layer (Figure 3). Much of the population of Coleoptera adults (22\%) and various other macrofauna $(38 \%)$, i.e. mostly litter feeders and their respective predators, are concentrated in the litter (Figure $3 \mathrm{~A}$ ). In the upper $10 \mathrm{~cm}$ of soil, geophagous invertebrates are predominant, with $85 \%$ of Oligochaeta and $75 \%$ of the Coleoptera larvae. In the lower layers $(10-30 \mathrm{~cm})$, the most abundant groups were the Isoptera (43\%), Diptera larvae (32\%) and Formicidae (30\%). Isoptera was the most abundant group ( $46 \%$ of total soil fauna density), and were predominantly found in the $0-20 \mathrm{~cm}$ layer $(85 \%)$.

Integrated crop-livestock systems could foster diverse cropping systems, including the use of perennial and legume forages, which could be grown
A

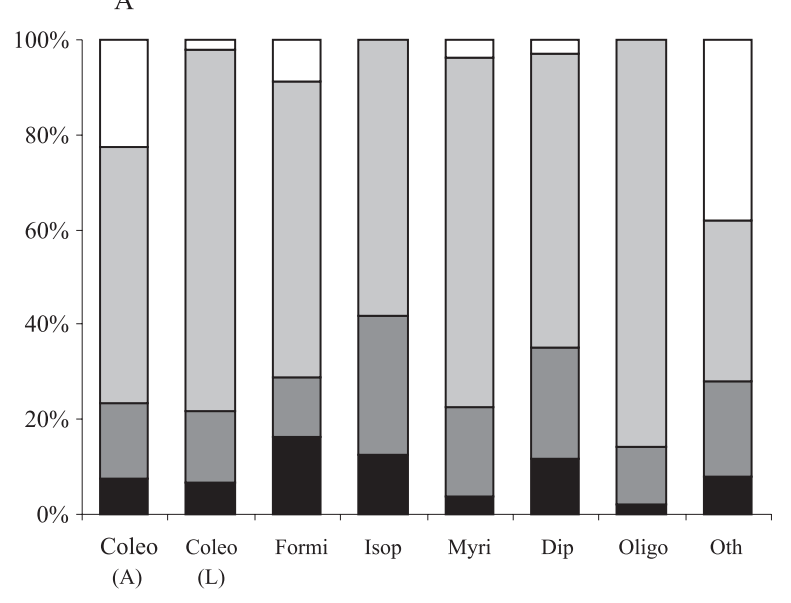

B

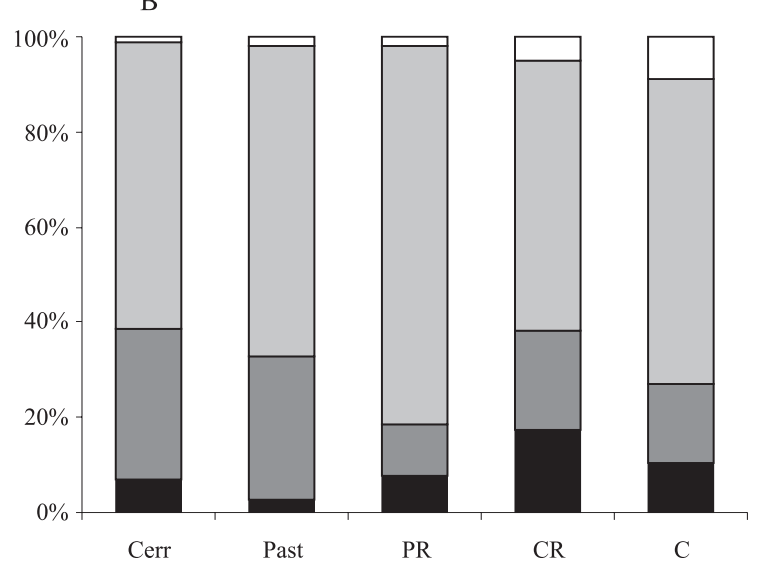

$\mathrm{C}$

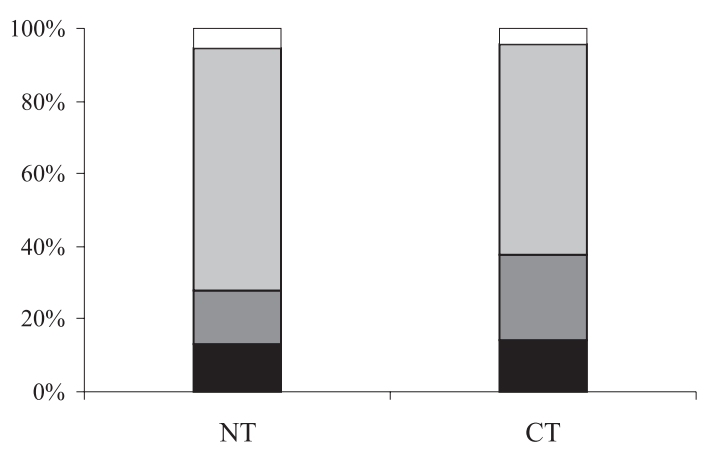

$\square$ Litter $\square 0-10 \mathrm{~cm} \square 10-20 \mathrm{~cm} \square 20-30 \mathrm{~cm}$

Figure 3. Vertical distribution of macrofauna in the litter and in the 0-10,10-20 and 20-30 cm soil layers for: A, taxonomic groups; B, management systems; and C, tillage regimes (in percent of the sum of the total density). Coleo (A), Coleoptera adult; Coleo (L), Coleoptera larvae; Formi, Formicidae; Isop, Isoptera; Myri, Myriapoda; Dip (L), Diptera; Oligo, Oligochaeta; Oth, Others, Cerr, Cerrado; C, continuous crop; CR, crop/pasture rotation; P, continuous pasture; PR, pasture/crop rotation; CT, conventional tillage; NT, no-tillage. 
in selected areas of the landscape to achieve multiple environmental benefits, as better soil conditions for macrofauna development, and represent systems which are useful for soil biodiversity conservation, in comparison to continuous systems. Since abundance and diversity of macroinvertebrate communities are associated with high rates of provision of the different ecosystem services provided by soils (Lavelle et al., 2006), the reasons for their increased conservation in these systems need to be better identified. This will allow a more precise management of this natural resource. Integrated systems would inherently utilize animal manure, which also enhances soil tilth, fertility, and carbon sequestration. However, more studies are needed to identify the best possible combinations of plant species and spatial arrays, to allow optimal production and sustainability.

\section{Conclusions}

1. Soil management systems and soil tillage regimes influence the structure of macrofauna communities with a greater density of Oligochaeta and Coleoptera larvae in continuous and in rotation pasture.

2. Crop-livestock rotation (crop-pasture and pasture-crop rotations), and no-tillage systems have a greater richness of Oligochaeta, Coleoptera larvae and Diptera larvae.

\section{Acknowledgements}

To Embrapa Cerrados and Embrapa Arroz e Feijão, Brazil, for technical and financial support; to the Institut de Recherche pour le Développement (IRD), France, for scholarship.

\section{References}

AQUINO, A.M. de; SILVA, R.F. da; MERCANTE, F.M.; CORREIA, M.E.F.; GUIMARÃES, M. de F.; LAVELlE, P. Invertebrate soil macrofauna under different ground cover plants in the no-till system in the Cerrado. European Journal of Soil Biology, v.44, p.191-197, 2008.

BALBINO, L.C.; BRUAND, A.; COUSIN, I.; BROSSARD, M.; QUÉTIN, P.; GRIMALDI, M. Change in the hydraulic properties of a Brazilian clay Ferralsol on clearing for pasture. Geoderma, v.120, p.297-307, 2004.

BARROS, E.; CURMI, P.; HALlAIRE, V.; CHAUVEL, A.; LAVELLE, P. The role of macrofauna in the transformation and reversibility of soil structure of an Oxisol in the process of forest to pasture conversion. Geoderma, v.100, p.193-213, 2001.
BARROS, E.; PASHANASI, B.; CONSTANTINO, R.; LAVELLE, P. Effects of land use system on the soil macrofauna in Western Brazilian Amazonia. Biology and Fertility of Soils, v.35, p.338-347, 2002.

BENITO, N.P.; BROSSARD, M.; PASINI, A.; GUIMARÃES, M. de F.; BOBILLIER, B. Transformations of soil macroinvertebrate populations after native vegetation conversion to pasture cultivation (Brazilian Cerrado). European Journal of Soil Biology, v.40, p.147-154, 2004.

BLANCHART, E.; LAVELLE, P.; BRAUDEAU, E.; LE BISSONAIS, Y.; VALENTIN, C. Regulation of soil structure by geophagous earthworm activities in humid savannas of Côte d'Ivoire. Soil Biology Biochemistry, v.29, p.431-439, 1997.

BROSSARD, M.; LÓPEZ-HERNÁNDEZ, D. Soil and environmental sustainability indicators for South America's savannas. Natures Sciences Sociétés, v.13, p.266-278, 2005.

BROWN, G.G.; FRAGOSO, C.; BAROIS, I.; ROJAS, P.; PATRÓN, J.C.; BUENO, J.; MORENO, A.G.; LAVELLE, P.; ORDAZ, V.; RODRÍGUEZ, C. Diversidad y rol funcional de la macrofauna edáfica en los ecosistemas tropicales mexicanos. Acta Zoologica Mexicana, v.1, p.79-110. 2001.

BROWN, G.G.; MORENO, A.G.; BAROIS, I.; FRAGOSO, C.; ROJAS, P.; HERNÁNDEZ, B.; PATRÓN, J.C. Soil macrofauna in SE Mexican pastures and the effect of conversion from native to introduced pastures. Agriculture, Ecosystems and Environment, v.103, p.313-327, 2004.

CONSTANTINO, R. Padrões de diversidade e endemismo de térmitas no bioma Cerrado. In: SCARIOT, A.; SOUZA-SILVA, J.C.; FELFILI, J.M. (Ed.). Cerrado: ecologia, biodiversidade e conservação. Brasília: Ministério do Meio Ambiente, 2005. 439p.

DECAËNS, T.; JIMÉNEZ, J.J.; BARROS, E.; CHAUVEL, A.; BLANCHART, E.; LAVELLE, P. Soil macrofauna communities in permanent pastures derived from tropical forest or savanna. Agriculture, Ecosystems and Environment, v.103, p.301-312, 2004.

DECAËNS, T.; LAVELLE, P.; JAEN, J.J.J.; ESCOBAR, G.; RIPPSTEIN, G. Impact of land management on soil macrofauna in the Oriental Llanos of Colombia. European Journal of Soil Biology, v.30, p.157-168, 1994.

DIAS, V.S.; BROSSARD, M.; LOPES-ASSAD, M.L. Macrofauna edáfica invertebrada em áreas de vegetação nativa da região de Cerrados. In: LEITE, L.L.; SAITO, C.H. (Ed.). Contribuição ao conhecimento ecológico do Cerrado. Brasília: Universidade de Brasília, 1997. p.168-173. Trabalhos selecionados do $3^{\circ}$ Congresso de Ecologia do Brasil.

FOOD AND AGRICULTURE ORGANIZATION OF THE UNITED NATIONS. World reference base for soil resources 2006. Rome: Food and Agriculture Organization of the United Nations, 2006. 128p. (World Soil Resources Reports, 103).

FRAGOSO, C.; BROWN, G.G.; PATRÓN, J.C.; BLANCHART, E.; LAVELLE, P.; PASHANASI, B.; SENAPATI, B.; KUMAR, T. Agricultural intensification, soil biodiversity and agroecosystem function in the tropics: the role of earthworms. Applied Soil Ecology, v.6, p.17-35, 1997. 
LAVELLE, P. Assessing the abundance and role of invertebrate communities in tropical soils: aims and methods. Journal of African Zoology, v.102, p.275-283, 1988.

LAVELLE, P.; BLANCHART, E.; MARTIN, A.; MARTIN, S.; BAROIS, I.; TOUTAIN, F.; SPAIN, A.; SCHAEFER, R. A hierarchical model for decomposition in terrestrial ecosystems. Application to soils in the humid tropics. Biotropica, v.25, p.30-150, 1993.

LAVELLE, P.; DECAËNS, T.; AUBERT, M.; BAROT, S.; BLOUIN, M.; BUREAU, F.; MARGERIE, F.; MORA, P.; ROSSI, J.P. Soil invertebrates and ecosystem services. European Journal of Soil Biology, v.42, p.3-15, 2006.

MARCHÃO, R.L.; BECQUER, T.; BRUNET, D.; BALBINO, L.C.; VILELA, L.; BROSSARD, M. Carbon and nitrogen stocks in a Brazilian clayey Oxisol: 13-year effects of integrated crop-livestock management systems. Soil Tillage Research, v.103, p.442-450, 2009.

MATHIEU, J.; ROSSI, J.P.; MORA, P.; LAVELLE, P.; MARTINS, P.F.; ROULAND, C.; GRIMALDI, M. Recovery of soil macrofauna communities after forest clearance in Eastern Amazonia, Brazil. Conservation Biology, v.19, p.1598-1605, 2005.

OADES, J.M. The role of biology in the formation, stabilization and degradation of soil structure. Geoderma, v.56, p.377-400, 1993.
SANTOS, G.G.; SILVEIRA, P.M. da; MARCHÃO, R.L.; BECQUER, T.; BALBINO, L.C. Macrofauna edáfica associada a plantas de cobertura em plantio direto em um Latossolo Vermelho do Cerrado. Pesquisa Agropecuária Brasileira, v.43, p.115-122, 2008.

SANTOS, H.G. dos; JACOMINE, P.K.T.; ANJOS, L.H.C. dos; OLIVEIRA, V.A. de; OLIVEIRA, J.B. de; COELHO, M.R.; LUMBRERAS, J.F.; CUNHA, T.J.F. (Ed.). Sistema brasileiro de classificação de solos. $2^{\text {nd }}$ ed. Rio de Janeiro: Embrapa Solos, 2006. 306p.

SILVA, R.F. da; AQUINO, A.M. de; MERCANTE, F.M.; GUIMARÃES, M. de F. Macrofauna invertebrada do solo sob diferentes sistemas de produção em Latossolo da Região do Cerrado. Pesquisa Agropecuária Brasileira, v.41, p.697-704, 2006.

THIOULOUSE, J.; CHESSEL, D.; DOL'EDEC, S.; OLIVIER J.M. ADE-4: a multivariate analysis and graphical display software. Statistics and Computing, v.7, p.75-83, 1997.

THOMAS, F.; FOLGARAIT, P.; LAVELLE, P.; ROSSI, J.P. Soil macrofaunal communities along an abandoned rice field chronosequence in Northern Argentina. Applied Soil Ecology, v.27, p.23-29, 2004.

Received on September 29, 2008 and accepted on July 3, 2009 